\title{
Performance and Emission Studies of a Naturally Aspirated Diesel Engine
}

\author{
S. Murugan, Kapura Tudu, and S. K. Patel
}

\begin{abstract}
Tyre recycling is one of the attractive solutions considered today, for the waste management of automobile waste tyres. In a practical tyre recycling plant that follows vacuum pyrolysis, light fraction pyrolysis oil(LFPO), heavy fraction pyrolysis oil(HFPO), non-condensable gas, carbon black and less fraction of steel wire are produced. Early investigations carried out by the authors reveal that a blend comprising $60 \%$ light fraction tyre pyrolysis oil(LFPO) and $40 \%$ diesel fuel(40LFPO) in it can be used an optimum blend percentage and used as an alternative fuel in a single cylinder, four stroke, direct injection(DI) diesel engine. Although the engine was able to run with the 40LFPO blend, the ignition delay for the 40LFPO blend was found to be longer than that of diesel operation in the entire load spectrum. In this study, the effect of adding small quantities of an ignition improver with the $40 L F P O$ on the performance and emissions of a single cylinder, four stroke, air cooled, direct injection (DI) diesel engine developing power of a $4.4 \mathrm{~kW}$ at a rated speed of $1500 \mathrm{rpm}$ was studied. For this purpose, Diethyl ether, an ignition improver (DEE) in small quantities from $1-4 \%$ on volume basis was blended with the 40LFPO accordingly. The blends were denoted as $X 1, X 2, X 3$ and $X 4$ where $X$ indicates the mixture of 40LFPO and DEE and the numeric value indicates the percentage of DEE in it. The results of the performance and emissions of the engine run on different DEE blends and compared with those of diesel operation presented in this paper.
\end{abstract}

Index Terms-Diesel engine, diethyl ether, emissions, light fraction pyrolysis oil, performance.

\section{INTRODUCTION}

One of the important problems currently faced by the humanity is disposal of different wastes that originate everywhere [1]. Different wastes are present in houses, villages, municipalities, agricultural lands and industries, and they are found in the form of solid, liquid and gas. It is impossible to completely avoid disposal of wastes. But, it can be minimized by adopting effective waste management practices. Generally, wastes can be categorized into two types viz., (i) non reusable, and (ii) recyclable and reuse. A few examples of non-reusable wastes are broken glass, broken concrete and some of the liquid effluents. Most of the organic wastes can be considered as recyclable or reusable. Few examples include food waste, textile waste, wood waste and agricultural waste. Waste to energy (W2E) is one of the methods adopted in recycling of organic wastes. Among all the wastes available for waste to energy process, automobile tyres and waste plastics are believed to have adequate

Manuscript received July 14, 2016; revised December 3, 2016.

The authors are with the National Institute of Technology, Rourkela, Odisha, India (e-mail: murugans@nitrkl.ac.in, kapura07.09@gmail.com, murugans@nitrkl.ac.in). potential of energy source, as they are disposed in a large quantity throughout the world [2]-[6]. Pyrolysis is one of the methods for converting waste automobile tyres into energy and value added products.

In pyrolysis process, the waste tyres are heated in a closed vessel by external heating with the presence of little oxygen. The evolving volatiles in the pyrolysis reactor are condensed in a condenser to obtain the value added energy or chemicals. Generally, the temperature required for pyrolysis of tyres is in the range of $400-600^{\circ} \mathrm{C}$. The process offers three principal products namely; (a) pyrolysis oil, (b) pyrogas and (c) carbon black [7], [8]. In recent years, the recycling of waste tyres by pyrolysis process has been found to be more attractive and technically feasible. There have been several tyre recycling pilot level and demonstrative plants installed, and commissioned in the world. In such a pyrolysis plant that follows vacuum pyrolysis process; four products are obtained such as, (i) light and heavy fraction oils, (ii) pyro gas, (iii) carbon black and (iv) steel wire. The light and heavy fraction oils are obtained in different condensers, based on the method of condensing the volatiles that are evolved from the pyrolysis reactor [7]-[15].

Tudu et al. [16] have recently made an attempt to use the light fraction pyrolysis oil (LFPO) obtained from a tyre recycling plant as an alternative fuel in the form of blends with diesel, in a stationary single cylinder, four stroke diesel engine. The LFPO was obtained from the first distillation column of a pyrolysis plant that was used to recycle waste automobile tyres through vacuum pyrolysis method. In that study, $20-60 \%$ of LFPO in steps of $20 \%$ of volume was blended with diesel fuel, and used as fuels in a single cylinder, four stroke, air cooled, DI diesel engine developing a power of $4.4 \mathrm{~kW}$ at a constant speed of $1500 \mathrm{rpm}$. The blends were denoted as XLFPO, where $\mathrm{X}$ indicated the percentage volume of LFPO in the LFPO-diesel blend. The combustion, performance and emissions of the engine were determined, analyzed and compared to those of diesel operation in the same engine. The results revealed that the 40LFPO ( $40 \%$ LFPO in the blend) gave better performance and lower emissions than those of 20LFPO and 60LFPO at full load. However, the results were found to be inferior to those obtained with the diesel fuel operation, which was owing to its lower cetane number and higher density. When the engine was able to run with different LFPO-diesel blends in a single cylinder, DI diesel engine, the engine exhibited inferior to those obtained with the diesel fuel operation. Due to the lower cetane number and higher density of the blends, the ignition of the 40LFPO blend started a little later, and the ignition delay was found to be longer. Injection timing is an important factor that affects the engine behavior in all means. 
Research reports indicate that the use of fuels with a high cetane number or ignition improver with a low cetane number fuel in the form of blends in CI engines would improve the engine behavior in terms of combustion and performance, while reducing the emissions in CI engines [17]-[20]. Running a CI engine fuelled with a low cetane fuel in the dual fuel mode can also improve the combustion behavior of the engine. Diethyl ether (DEE) is a good example of an ignition improver, whose cetane number is greater than 125 , and it is an oxygenated fuel. It can be derived from various biomass materials at a cheaper cost [21]. Experimental investigations were carried out to study the effect of blending DEE in small quantities with diesel [22], ethanol-diesel blend [23], kerosene [24], orange oil [25], diesel water emulsion [26], bio-oil and biodiesel obtained from Jatropha [27], Pongamia [28], Mahua [29], Palm oil [30], Cotton seed oil [31], Neem oil [32], and Soybean [33] on the engine behavior, in terms of the performance, emission and combustion parameters of DI diesel engines. Most of the investigation results suggested that there was a possibility of simultaneous reduction of $\mathrm{NO}_{\mathrm{x}}$ and smoke emissions with improved performance. The main reasons stated for the reduction in the $\mathrm{NO}_{\mathrm{x}}$ emission were improved cetane number, higher latent heat of vaporisation, and higher viscosity of the blend in some cases. The reduction in the smoke emission was attributed to the presence of oxygen, supplemented either by the DEE or the blend. In some experimental studies, DEE was fumigated in CI engines in which diesel [31], biodiesel [32], tyre pyrolysis oil [33], biodiesel-bioethanol blend [33], and orange oil [35] were used as pilot fuels.

It was reported that, the dual fuel mode offered improved brake thermal efficiency, and reduced smoke emission in comparison with those of neat diesel operation at part and full loads. The reason mentioned for the reduction in the smoke emission was the higher flame velocity of DEE and the presence of oxygen in it. DEE is a highly volatile flammable liquid [36]. It can easily catch fire and spread the flame very quickly [37]. Some researchers have reported that the $\mathrm{NO}_{\mathrm{x}}$ emission was reduced, while some of them reported that the $\mathrm{NO}_{\mathrm{x}}$ emission was higher than that of diesel operation at full load. The reason for reduced $\mathrm{NO}_{\mathrm{x}}$ emission was the higher latent heat of vaporization, which reduced the maximum heat release rate in the premixed combustion phase. The reason for the higher $\mathrm{NO}_{\mathrm{x}}$ stated by some of the researchers was the spontaneous ignition of DEE which enhanced the premixed combustion. Some researchers have used dimethyl ether (DME) as an ignition improver with diesel [38], biodiesel [39] and diesel water emulsion [40]. They have also reported similar results. Because of low cost and easy availability DEE was chosen as an ignition improver for this study.

In this study, the effect of adding small quantities of an ignition improver with the 40LFPO on the performance and emissions of a single cylinder, four stroke, air cooled, direct injection (DI) diesel engine developing power of a $4.4 \mathrm{~kW}$ at a rated speed of $1500 \mathrm{rpm}$ was studied. For this purpose, Diethyl ether, an ignition improver (DEE) in small quantities from $1-4 \%$ on volume basis was blended with the 40LFPO accordingly. The blends were denoted as X1, X2, X3 and X4 where $X$ indicates the mixture of 40LFPO and DEE and the numeric value indicates the percentage of DEE in it. The results of the performance and emissions of the engine run on different DEE blends and compared with those of diesel operation and presented in this paper.

\section{EXPERIMENTATION}

\section{A. Light Fraction Pyrolysis Oil (LFPO)}

For this investigation, LFPO was purchased from a tyre recycling demonstration plant that is installed and commissioned in India. The plant follows vacuum pyrolysis to recycle the segregated and crumbed automobile tyres. Fig. 1 illustrates the schematic layout of the pilot tyre pyrolysis plant.

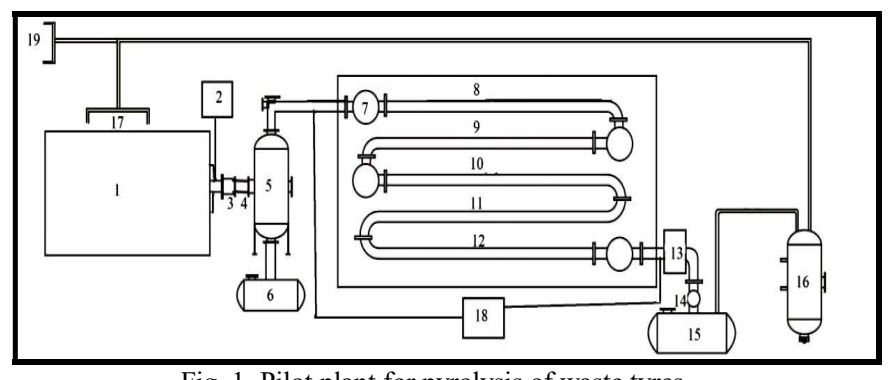

Fig. 1. Pilot plant for pyrolysis of waste tyres.

1. Reactor 2. Electric motor 3. Sealing elements 4. Flexible connection 5. Oil separator 6. Heavy oil tank 7. Damper 8-12. Condenser tubes 13. Cooling tower 14. Smooth inspection mirror 15. Light oil tank 16. Water sealing and gas recycling system 17. Gas burner 18. Pump 19. Control panel.

The plant has a cylindrical rotary type pyrolysis reactor (1). The plant has a batch process with a capacity of 10 tons. The length of the reactor is approximately $6.6 \mathrm{~m}$, and the diameter is $2.8 \mathrm{~m}$. The reactor is rotated with the help of an electric motor (2) and a pulley arrangement. The pyrolysis reactor is initially heated up by waste wood. The wood consumption per batch is about 2 tons. In the pilot plant, the shredded tyres are fed into the pyrolysis reactor. The front end of the reactor has a door with fasteners. The door can be opened or closed by unlocking or locking the fasteners. The other end of the reactor is connected to sealing elements (3) and a flexible connection (4). An oil separator (5) is connected to the reactor by the sealing element and the flexible connection. The volatile vapour evolves during pyrolysis, passes through the oil separator, where heavy oil is separated by gravity and collected in a heavy oil tank (6). A damper (7) is provided at the outlet of the oil separator that connects a bench of water cooled condenser tubes (8-12). Further, the volatile gases enter the bunch of water cooled condenser tubes, where the light oil fractions are converted into liquid. A cooling tower (13) is used to bring down the temperature of the coolant close to atmospheric temperature, which is used in the water cooled condenser. A smooth inspect mirror (14) is used to know whether the gas is converted into liquid or not. The light oil is collected in a tank (15). A certain quantity of gases, which is not condensed in the heavy oil tank passes through a water sealing (16) and enters the gas recycling system.

The non-condensable gas is cleaned in the gas recycling system, and then given to a gas burner (17), which is located in the reactor for heating. A pump (18) is used to recirculate the coolant leaving the cooling tower to the condenser. The pyrolysis reactor and the accessories are operated by motors 
and pumps with the help of a control panel. The initial temperature at which volatile vapours evolve in the reactor is around $160{ }^{\circ} \mathrm{C}$ at about four hours of plant operation. During the process, carbon black and steel are also generated.

The yields of products obtained in the plant a pilot plant are given below;

(a) Fuel oil (40-45\%) (b) Carbon black (30-35\%) (c) Steel wire $(3-5 \%)$

(d) Non-condensable gases (8-10\%) (e) Moisture (3-5\%)

\section{B. Engine Test Setup}

Experiments were conducted in a single cylinder, four stroke, air cooled, DI, diesel engine, with a developing power output of $4.4 \mathrm{~kW}$ at $1500 \mathrm{rpm}$. A schematic diagram of the experimental arrangement is shown in Fig. 2. Table I gives the details of the test engine. The fuel is supplied by the mechanical injection system to the engine. The fuel quantity is varied by a governor mechanism provided in the engine. For loading the engine, the brake shaft is coupled with an electrical dynamometer (Make: Kirloskar, WHD10075, ACG) assisted with a resistive load bank. A burette is provided between the fuel tank and the fuel pump. The level of fuel in the burette is sensed by a fuel sensor. The sensor gives input to the load cell which gives the data (difference in head) to the data acquisition system. The density, calorific values and load are manually entered in an excel sheet provided in the data acquisition system. With these data, fuel consumption is calculated by the computer and gives the output (brake specific fuel consumption). An air flow sensor connected after an air box, which measures the intake air flow rate. A temperature sensor installed near the exhaust manifold measures the exhaust gas temperature. An AVL DiGas444 exhaust gas analyzer measures the exhaust emissions such as unburnt hydrocarbon $(\mathrm{HC})$, carbon monoxide $(\mathrm{CO})$, carbon dioxide $\left(\mathrm{CO}_{2}\right)$ and nitric oxide $(\mathrm{NO})$. The $\mathrm{HC}, \mathrm{CO}$ and $\mathrm{CO}_{2}$ emissions are measured by the NDIR (non-dispersive infrared) principle. The NO emission is measured by an electrochemical sensor.

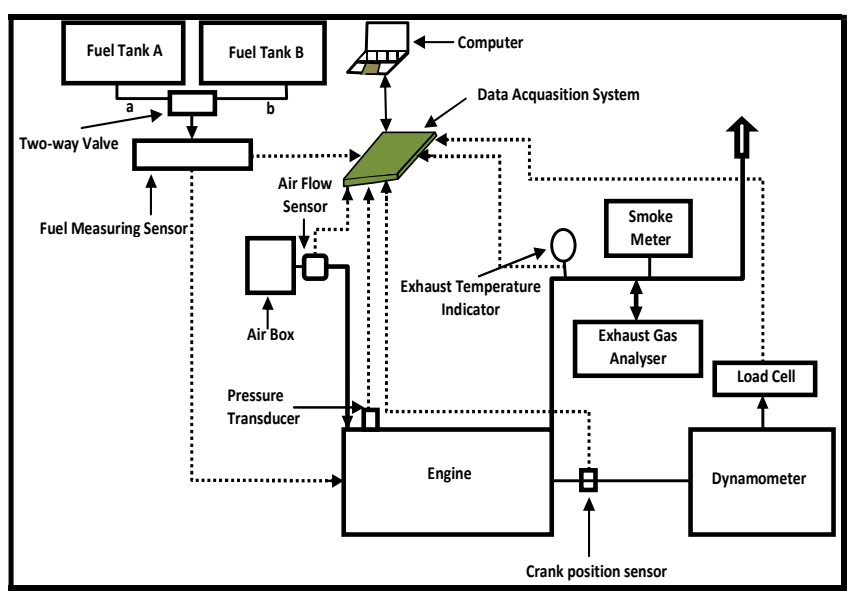

Fig. 2. Engine experimental setup.

The smoke opacity of the engine exhaust is measured with the help of an AVL437 diesel smoke meter that works on the principle of the Hartridge smoke meter. For loading the engine, the brake shaft was coupled with an electrical dynamometer (Make: Kirloskar, WHD10075, ACG) assisted with a resistive load bank. The sensor collects the data of voltage and current from the load cell and gives to the data acquisition system. Initially, the engine was run with diesel to obtain the reference data at no load, $25 \%, 50 \%, 75 \%$ and full load. After conducting all the tests with the blends, the engine was again run on diesel, to ensure that there was no fuel trace of different blends. In this investigation the DEE percentage was varied from 1 to $4 \%$. Some important properties are listed in Table II.

TABLE I: DETAILS OF THE TEST ENGINE

\begin{tabular}{|c|c|c|}
\hline Description & Unit & Data \\
\hline Name of the engine manufacturer & - & $\begin{array}{l}\text { Kirolaskar } \\
\text { oil engines Ltd. }\end{array}$ \\
\hline Type of engine & - & $\begin{array}{l}\text { Vertical, } \\
\text { 4-stroke cycle, } \\
\text { single acting, } \\
\text { diesel engine }\end{array}$ \\
\hline Rated speed & $\mathrm{rpm}$ & 1500 \\
\hline No. of cylinders & - & 1 \\
\hline Power output & $\mathrm{kW}$ & 4.41 \\
\hline Bore & $\mathrm{mm}$ & 87.5 \\
\hline Stroke & $\mathrm{mm}$ & 110 \\
\hline Cubic capacity & litres & 0.662 \\
\hline Compression ratio & & $17.5: 1$ \\
\hline Injection timing & ${ }^{\circ} \mathrm{CA}$ & 23 \\
\hline Method of cooling & & Air cooled with radial fan \\
\hline
\end{tabular}

TABLE II: PROPERTIES OF DIETHYL ETHER

\begin{tabular}{|c|c|c|}
\hline Properties & $\begin{array}{l}\text { ASTM } \\
\text { Method }\end{array}$ & DEE \\
\hline $\begin{array}{l}\text { Density }\left(\mathrm{kg} / \mathrm{m}^{3}\right. \\
\left.\text { (a) } 20{ }^{\circ} \mathrm{C}\right)\end{array}$ & D1298 & 730 \\
\hline $\begin{array}{l}\text { Kinematic viscosity } \\
\left(\mathrm{cSt} @ 40{ }^{\circ} \mathrm{C}\right)\end{array}$ & D445 & 0.23 \\
\hline Calorific value $(\mathrm{MJ} / \mathrm{kg})$ & D4809 & 33.9 \\
\hline Cetane number & D613 & 125 \\
\hline $\begin{array}{l}\text { Flash point by Abel method } \\
\left({ }^{\circ} \mathrm{C}\right)\end{array}$ & D93 & -40 \\
\hline Fire point $\left({ }^{\circ} \mathrm{C}\right)$ & D92 & 44 \\
\hline
\end{tabular}

The designation and composition of the 40LFPO based test fuels used in this module are given below;

a) $40 \mathrm{LFPO}(40 \% \mathrm{LFPO}+60 \%$ Diesel $)$

b) X1 (40\% LFPO + 59\% Diesel + 1\% DEE)

c) X2 $(40 \% \mathrm{LFPO}+58 \%$ Diesel $+2 \%$ DEE $)$

d) $\mathrm{X} 3(40 \% \mathrm{LFPO}+57 \%$ Diesel $+3 \% \mathrm{DEE})$

e) $\mathrm{X} 4(40 \% \mathrm{LFPO}+56 \%$ Diesel $+4 \%$ DEE $)$

The 40LFPO-DEE blend was stirred continuously with the help of a mechanical stirrer for about 30 minutes to ensure thorough mixing. The four test fuels namely, X1, X2, X3 and $\mathrm{X} 4$ were used in this investigation, where the numerical value indicates the percentage of DEE added to the 40LFPO blend. For example, X1 is a fuel that contains $40 \%$ LFPO, $1 \%$ DEE and $59 \%$ diesel. The compositions and designations of different 40LFPO-DEE blends are given in Table III.

\begin{tabular}{l|l|l|l}
\multicolumn{4}{c}{ TABLE III: COMPOSITIONS OF THE TEST BLENDS } \\
\hline Designation & LFPO (\%) & Diesel (\%) & DEE (\%) \\
& & & \\
\hline Diesel & 0 & 100 & 0 \\
\hline 40 LFPO & 40 & 60 & 0 \\
\hline X1 & 40 & 59 & 1 \\
\hline X2 & 40 & 58 & 2 \\
\hline X3 & 40 & 57 & 3 \\
\hline X4 & 40 & 56 & 4 \\
\hline
\end{tabular}


The physical properties of the 40LFPO and LFPO-DEE blends are listed in Table IV in comparison with those of diesel and 40LFPO.

TABLE IV: PhySiCAL PRoperties OF Diesel, 40LFPO, X1, X2, X3 AND X4

\begin{tabular}{lllllll}
\hline Properties & Diesel & $40 \mathrm{LFPO}$ & $\mathrm{X} 1$ & $\mathrm{X} 2$ & $\mathrm{X} 3$ & $\mathrm{X} 4$ \\
\hline $\begin{array}{l}\text { Density }\left(\mathrm{kg} / \mathrm{m}^{3}\right. \\
@\end{array}$ & 830 & 862 & 861 & 860 & 859 & 858 \\
$\left.20{ }^{\circ} \mathrm{C}\right)$ & & & & & & \\
\hline $\begin{array}{l}\text { Kinematic } \\
\text { viscosity } \\
(\mathrm{cSt} @\end{array}$ & 2.70 & 2.9 & 2.82 & 2.79 & 2.77 & 2.74 \\
$\left.40{ }^{\circ} \mathrm{C}\right)$ & & & & & & \\
\hline $\begin{array}{l}\text { Lower heating } \\
\text { value } \\
(\mathrm{MJ} / \mathrm{kg})\end{array}$ & 43.8 & 41.9 & 41.8 & 41.7 & 41.6 & 41.5 \\
\hline Cetane number & 50 & 41.2 & 41.9 & 42.6 & 43.4 & 44.2 \\
\hline Flash point $\left({ }^{\circ} \mathrm{C}\right)$ & 50 & 42 & 41.9 & 41.8 & 41.7 & 41.6 \\
\hline $\begin{array}{l}\text { Sulphur content } \\
(\% \mathrm{wt})\end{array}$ & 0.29 & 0.87 & 0.48 & 0.48 & 0.47 & 0.47 \\
\hline
\end{tabular}

\section{RESULTS AND DisCUSSION}

\section{A. Performance Parameters}

\section{1) Brake specific energy consumption}

The variation of brake specific energy consumption (BSEC) for diesel, 40LFPO and its DEE blends with respect to load are plotted and shown in Fig. 3.

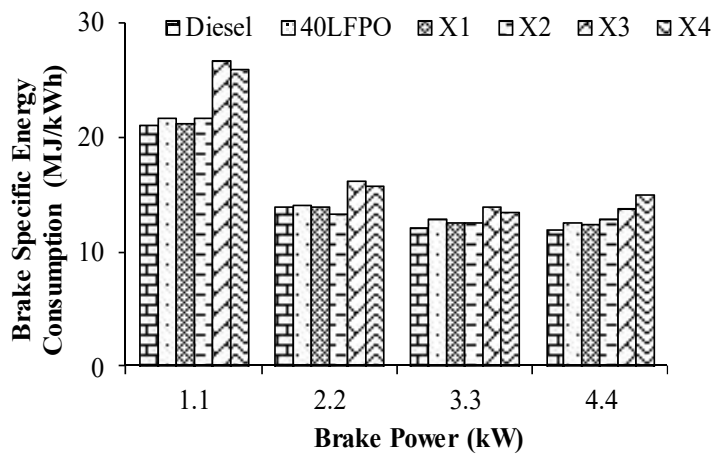

Fig. 3. Variation of brake specific energy consumption with brake power.

It can be observed from the figure that, as the load increases the BSEC decreases for all the fuels tested in this study. This is due to more amount of fuel being consumed to produce the same power output. The BSEC for diesel is the lowest among all the fuels tested in this study in the entyre range of engine operation, because of its higher heating value, lower density and fuel composition. The BSEC of the 40LFPO blend is marginally higher than that of diesel throughout the load spectrum. This is due to the higher density and lower heating value of the blend. Adding 1-2\% of DEE to 40LFPO reduces the BSEC to a maximum of 1 and $3 \%$ than that of diesel and $40 \mathrm{LFPO}$ respectively, at full load. Beyond $2 \%$, the addition of DEE increases the BSEC of the blend over that of diesel and 40LFPO. The reason may be the higher latent heat of vaporization of DEE that absorbs the heat of combustion. The $\mathrm{BSEC}$ of X4 is $16.9 \mathrm{M} \mathrm{J} / \mathrm{kWh}$ higher i.e., about $25 \%$ than that of diesel at full load. The BSEC of diesel, 40LFPO, X1, X2, $\mathrm{X} 3$ and $\mathrm{X} 4$ are about $11.8,12.6,12.4,12.7,14.7$ and 16.9 $\mathrm{MJ} / \mathrm{kWh}$ respectively.

\section{2) Exhaust gas temperature}

Fig. 3 illustrates the variation of the exhaust gas temperature (EGT) for diesel, and with and without the addition of diethyl ether (DEE) with 40LFPO. It can be observed from the figure that, as the load increases, the EGT increases throughout the load spectrum for diesel, 40LFPO $\mathrm{X} 1, \mathrm{X} 2, \mathrm{X} 3$ and $\mathrm{X} 4$ due to the increase in the quantity of fuel injected. The EGT varies from 338 to $339^{\circ} \mathrm{C}$ at full load for all the blends. The EGT reduces with the addition of DEE. This may be due to a reduced ignition delay as a result of the increase in the cetane number.

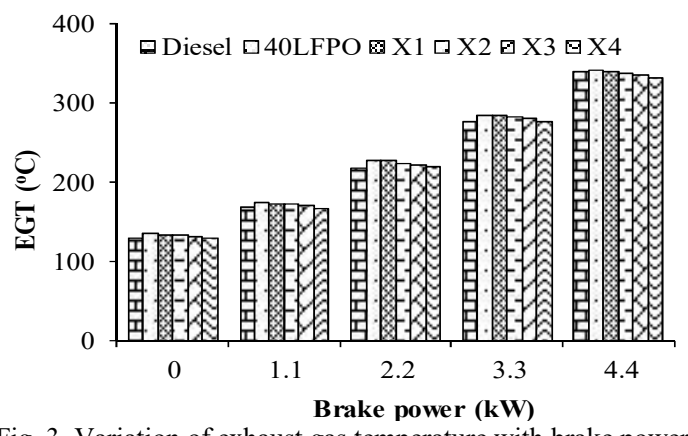

Fig. 3. Variation of exhaust gas temperature with brake power.

Similar reason is supported by Cinar et al., for the results obtained in a single cylinder four stroke CI engine, which was run by diesel doped with carbon black. The EGT for X4 is lower compared to other blends, the reason of which may be the highest percentage of DEE compared to the other blends. The values of the exhaust gas temperatures of diesel, 40LFPO, $\mathrm{X} 1, \mathrm{X} 2, \mathrm{X} 3$ and $\mathrm{X} 4$ are about 338.5, 339.2, 337.3, 336. $4,334.2$ and $330.5^{\circ} \mathrm{C}$ respectively.

\section{B. Emission Parameters}

\section{1) Nitric oxide emission}

The variations of NO emissions with load for the fuels tested in this study are depicted in Fig. 4. It can be observed from the figure that, diesel operation exhibits the highest NO emission among all the fuels tested in this study. Diesel has better fuel characteristics in comparison with 40LFPO and its DEE blends. Due to the higher density of 40LFPO, the combustion is incomplete and results in a lower NO emission for the given power output. The addition of more DEE percentage might reduce the cylinder temperature as a result of its higher latent heat of vaporization which results in lower $\mathrm{NO}$ emission than that of diesel operation for the given power output.

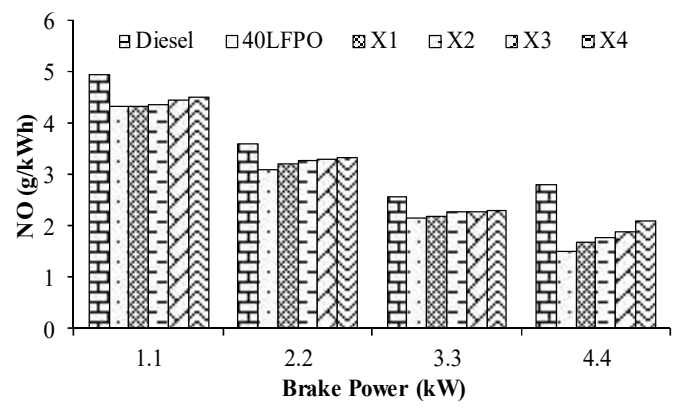

Fig. 4. Variation of nitric oxide emission with brake power.

However, the NO emission of the 40LFPO-DEE blend 
increases with an increase in DEE percentage at all loads. It can also be observed from the figure that the NO emission is increased by the addition of DEE in 40LFPO and diesel blends for the entyre load spectrum. The reason may be due to DEE, which has high volatility and oxygen that provides complete combustion. The NO emission of X4 is higher by about $2.09 \mathrm{~g} / \mathrm{kWh}$ among the other 40LFPO-DEE blends at full load. The NO emission of X4 is approximately about $25 \%$ lower compared to that of diesel, and about $20 \%$ higher compared to that of 40LFPO blend at full load.

\section{2) Carbon dioxide emission}

Carbon dioxide $\left(\mathrm{CO}_{2}\right)$ emission indicates complete combustion, due to sufficient amount of oxygen being available in the air-fuel mixture, or sufficient time in the cycle for complete combustion. Fig. 5 portrays the variation of $\mathrm{CO}_{2}$ emission with respect to load for diesel, 40LFPO and its DEE blends.

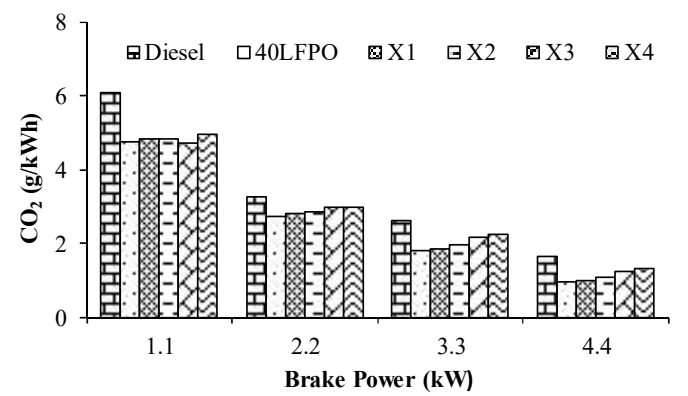

Fig. 5. Variation of carbon dioxide emission with brake power.

It can be observed from the figure that the diesel operation produces the highest $\mathrm{CO}_{2}$ emission among all the fuels tested in this study, as a result of more complete combustion of fuel. The higher density and lower volatility of 40LFPO result in lower $\mathrm{CO}_{2}$ emission throughout the engine operation in comparison with diesel operation. When DEE is added to the 40LFPO blend, the $\mathrm{CO}_{2}$ emission is increased in the entyre load spectrum. The $\mathrm{CO}_{2}$ emission for $\mathrm{X} 4$ is higher by about $1.3 \mathrm{~g} / \mathrm{kWh}$ compared to the X1, X2 and X3 blends. The oxygen present in the DEE may promote the combustion of the LFPO-DEE blend, and hence, a marginally higher amount of $\mathrm{CO}_{2}$ is produced than that of 40LFPO. The $\mathrm{CO}_{2}$ emission for $\mathrm{X} 4$ is approximately about $18 \%$ lower compared to that of diesel, and about $22 \%$ higher compared to that of $40 \mathrm{LFPO}$ blend at full load.

\section{3) Hydrocarbon emission}

Fig. 6 depicts the variation of $\mathrm{HC}$ emission with load for the different fuels tested in this study.

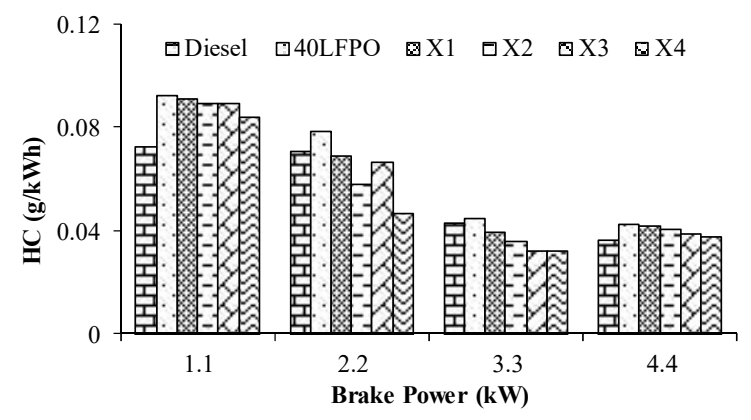

Fig. 6. Variation of hydrocarbon emission with brake power.
The $\mathrm{HC}$ emission occurs in a CI engine due to incomplete combustion and the variation of $\mathrm{HC}$ emission levels, with respect to equivalence ratio and deposits on the wall. The HC emission of the diesel engine is primarily influenced by fuel quality and the oxygen availability for complete combustion. It is also influenced by the ignition delay, rate of reaction and engine design. The 40LFPO operation exhibits higher HC emission than that of diesel operation throughout the load spectrum. The higher aromatic content and poor mixture formation may be the reasons for the higher $\mathrm{HC}$ emission. With the 40LFPO blend, the $\mathrm{HC}$ concentration ranges from 0.036 to $0.037 \mathrm{~g} / \mathrm{kWh}$ at full load operation. It can also be observed that the $\mathrm{HC}$ concentration with $4 \%$ addition of DEE is lower compared to that of all the blends throughout the engine operation. The reason may be the addition of DEE, which provides oxygen to improve the oxidation. The $\mathrm{HC}$ emissions for diesel, 40LFPO, X1, X2 and X3 are about 0.036 , $0.042,0.041,0.040,0.038$ and $0.037 \mathrm{~g} / \mathrm{kWh}$ at full load respectively. The $\mathrm{HC}$ emission of $\mathrm{X} 4$ is approximately about $2.7 \%$ higher compared to that of diesel and about $14 \%$ lower compared to that of the 40LFPO blend.

\section{4) Carbon monoxide emission}

The carbon monoxide (CO) emission is an indication of the incomplete combustion of the fuel air mixture that takes part in the combustion process. $\mathrm{CO}$ is generated, when an engine is operated with a rich mixture. Diesel engines generally produce lower $\mathrm{CO}$ emission as they run on lean mixture. Fig. 7 illustrates the variation of $\mathrm{CO}$ emission with brake power for diesel, 40LFPO and its DEE blends.

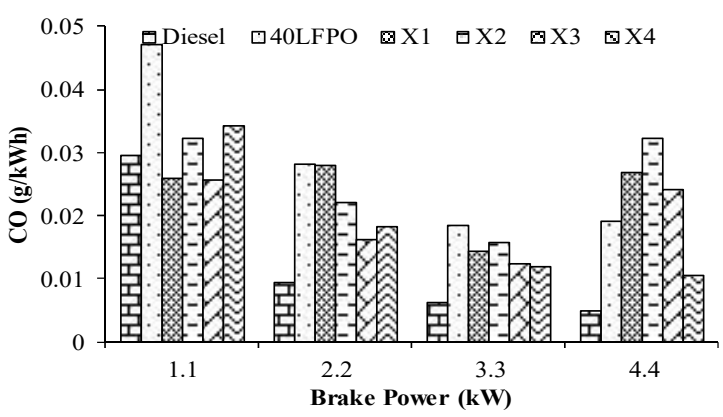

Fig. 7. Variation of carbon monoxide emission with brake power.

It can be observed from the figure that as the load increases the $\mathrm{CO}$ emission decreases but at full load it again increases. This is due to maximum fuel supply at full load to overcome the higher load, which provides rich mixture and therefore, $\mathrm{CO}$ emission occurred. The $\mathrm{CO}$ emission is the highest for 40LFPO in this study. However, the addition of DEE with the 40LFPO-diesel blends results in reduced $\mathrm{CO}$ emission, which is due to more oxygen being available for combustion than in 40LFPO. At full load, X4 gives lower CO emission of about $45 \%$ for the 40 LFPO blend.

\section{5) Smoke emission}

The variation of smoke emission, with brake power for diesel, 40LFPO and its DEE blends are depicted in Fig. 8. The smoke emission increases with an increase in the load. This is due to the increase in the mass of fuel consumed when brake power is increased. The smoke emission for the 40LFPO blend is found to be the highest at full load. The value of 
smoke emission for diesel and 40LFPO are 61.2 and $69.2 \%$ respectively at full load. Adding DEE to $40 \mathrm{LFPO}$ blend, the smoke emission reduces, and the values for X1, X2, X3 and $\mathrm{X} 4$ are $56,50,45,48 \%$ are respectively at full load. The smoke emission for $\mathrm{X} 3$ is found to be the lowest in this investigation. The volatility and oxygen enrichment provided by DEE is beneficial in improving the fuel evaporation and smoke reduction.

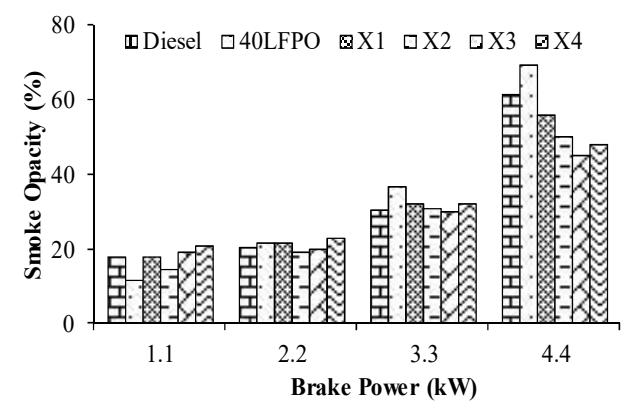

Fig. 8. Variation of smoke emission with brake power.

The smoke emissions of X3, X4 are approximately 26 and $21 \%$ lower compared to that of diesel, and about $39 \%, 34 \%$ lower compared to that of the 40LFPO blend at full load.

\section{CONCLUSION}

The combustion, performance and emission parameter characteristics of the test engine run on 40LFPO and its different DEE blends were evaluated, analyzed and compared with those of diesel operation. The following conclusions are drawn from the present investigation:

- The addition of DEE improves the performance, combustion and reduces the smoke emission.

- The BSFC of the X4 blend is $6 \%$ lower compared to that of diesel at full load.

- The ignition delay of the 40LFPO-DEE blends is reduced by about $1-2^{\circ} \mathrm{CA}$ at full load.

- The values of the peak cylinder pressures for X1, X2, X3 and $\mathrm{X} 4$ are $73.5,74.2,75.9$ and 76.9 bar respectively at full load.

- The addition of 4\% DEE to the 40LFPO diesel blend, gives better results in terms of combustion and lower $\mathrm{CO}$ emission compared to all the blends studied. The 3\% DEE for smoke emission is the lowest among all the fuels studied.

- The NO emission of X4 is approximately $25 \%$ lower compared to that of diesel and about $20 \%$ higher compared to that of the 40LFPO blend at full load.

- The smoke emissions of X3 and X4 are found to be approximately 26 and $21 \%$ lower compared to that of diesel, and about 39 and 34\% lower compared to that of the $40 \mathrm{LFPO}$ blend at full load.

\section{REFERENCES}

[1] United States Environmental Protection Agency. [Online]. Available: http://www.epa.gov/region2/superfund/green-remediation/policy.html

[2] Y. C. Chang, W. J. Lee, L. C. Wang, H. H. Yang, M. T. Cheng, J. H. Lu, Y. I. Tsai and L. H. Young, "Effects of waste cooking oil-based biodiesel on the toxic organic pollutant emissions from a diesel engine," Applied Energy, vol. 113, pp. 631-638, 2014.
[3] R. Taylor and A. Allen, Waste Disposal and Landfill: Information Needs, Ch. 12, pp. 1-22, 2006.

[4] S. Murugan and S. Gu, "Research and development activities in pyrolysis - Contributions from Indian scientific community: A review," Renewable and Sustainable Energy Reviews, vol. 46, pp. 282-295, 2015.

[5] Urban waste management strategy, international environmental technology centre, United Nations Environment Program, pp. 1-14, 2003.

[6] J. I. Reisman, E. H. Pechan and Inc. Associates, "Air emissions from scrap tyre combustion," United States Environmental Protection Agency, EPA-600/R-97-115, 1997

[7] Y. M. Chang, "On pyrolysis of waste tyre: Degradation rate and product yields," Resources, Conservation and Recycling, vol. 17, no. 2, pp. 125-139, 1996

[8] A. Zabaniotou, P. Madau, P. D. Oudenne, C. G. Jung, M. P. Delplancke, and A. Fontana, "Active carbon production from used tyre in two-stage procedure: Industrial pyrolysis and bench scale activation with H2O-CO2 mixture," Journal of Analytical and Applied Pyrolysis, vol. 72, no. 2, pp. 289-297, November 2004.

[9] S. Murugan, M. R. C. Ramaswamy, and G. Natarajan, "Influence of distillation on performance, emission, and combustion of a di diesel engine, using tyre pyrolysis oil diesel blends," Thermal Science, vol. 12, no. 1, pp. 157-167, 2008

[10] S. Murugan, M. C. Ramaswamy, and G. Nagarajan, "Assessment of pyrolysis oil as an energy source for diesel engines," Fuel Processing Technology, vol. 90, no. 1, pp. 67-74, 2009.

[11] O. Dogan, M. B. Celik, and B. Özdalyana, "The effect of tyre derived fuel/diesel fuel blends utilization on diesel engine performance and emissions," Fuel, vol. 95, pp. 340-346, 2012.

[12] A. B. Koc and M. Abdullah, "Performance of a 4-cylinder diesel engine running on tyre oil-biodiesel-diesel blend," Fuel Processing Technology, vol. 118, pp. 264-269, 2014.

[13] S. Frigo, M. Seggiani, M. Puccini, and S. Vitolo, "Liquid fuel production from waste tyre pyrolysis and its utilization in a Diesel engine," Fuel, vol. 116, pp. 399-408, 2014

[14] J. D. Martínez, J. Rodríguez-Fernández, J. Sánchez-Valdepeñas, R. Murillo, and T. García, "Performance and emissions of an automotive diesel engine using a tyre pyrolysis liquid blend," Fuel, vol. 115, pp. 490-499, 2014.

[15] J. D. Martínez, Á. Ramos, O. Armas, R. Murillo and T. García "Potential for using a tyre pyrolysis liquid-diesel fuel blend in a light duty engine under transient operation", Applied Energy, vol. 130, p. 437-446, 2014.

[16] K. Tudu, S. Murugan, and S. K. Patel, "Experimental analysis of a DI diesel engine fuelled with light fraction of pyrolysis oil," International Journal of Oil, Gas and Coal Technology, vol. 11, no. 3, 2016.

[17] L. Xing-cai, Y. Jian-Guang, Z. Wu-Gao, and H. Zhen, "Effect of cetane number improver on heat release rate and emissions of high speed diesel engine fuelled with ethanol-diesel blend fuel," Fuel, vol. 83, no. 14, pp. 2013-2020, 2004.

[18] Y. Ren, Z. Huang, H. Miao, Y. Di, D. Jiang, K. Zeng, B. Liu, and X Wang, "Combustion and emissions of a DI diesel engine fuelled with diesel-oxygenate blends," Fuel, vol. 87, no. 12, pp. 2691-2697, 2008.

[19] D. Hansdah, B. Suna, and M. Sivalingam, "Experimental analysis of diesel engine fuelled with e-diesel produced from madhuca indica flowers with the addition of an ignition improver," SAE Technical Paper, No. 2013-01-1700, 2013.

[20] R. Munsin, Y. Laoonual, S. Jugjai, M. Matsuki, and H. Kosaka, "Effect of glycerol ethoxylate as an ignition improver on injection and combustion characteristics of hydrous ethanol under CI engine condition," Energy Conversion and Management, vol. 98, pp. 282-289, 2015.

[21] I. Sezer, "Thermodynamic, performance and emission investigation of a diesel engine running on dimethyl ether and diethyl ether," International Journal of Thermal Science, vol. 50, no. 8, pp. 1594-1603, 2011.

[22] B. Bailey, J. Eberhardt, S. Goguen, and J. Erwin, "Diethyl ether (DEE) as a renewable diesel fuel," SAE Technical Paper 972978, 1997.

[23] W. Tutak, A. Jamrozik, M. Pyrc, and M. Sobiepański, "Investigation on combustion process and emissions characteristic indirect injection diesel engine powered by wet ethanol using blend mode," Fuel Processing Technology, vol. 149, pp. 86-95, 2016.

[24] K. R. Patil and S. S. Thipse, "Experimental investigation of CI engine combustion, performance and emissions in DEE-kerosene-diesel blends of high DEE concentration," Energy Conversion and Management, vol. 89, pp. 396-408, 2015. 
[25] K. Purushothaman and G. Nagarajan, "Performance, emission and combustion characteristics of a compression ignition engine operating on neat orange oil," Renewable Energy, vol. 34, p. 242-245, 2009.

[26] A. K. Wamankar and S. Murugan, "Experimental investigation of carbon black-water-diesel emulsion in a stationary DI diesel engine," Fuel Processing Technology, vol. 125, p. 258-266, 2014.

[27] S. Imtenan, H. H. Masjuki, M. Varman, M. A. Kalam, M. I. Arbab, H. Sajjad and S. M. A. Rahman, "Impact of oxygenated additives to palm and jatropha biodiesel blends in the context of performance and emissions characteristics of a light-duty diesel engine," Energy Conversion and Management, vol. 83, p. 149-158, 2014.

[28] A. H. Lenin, N. Azhagesan, C. R. B. S. Rex and K. Thyagarajan, "Performance of diesel engine operating with pongamia methyl ester as a biodiesel," Asian Journal of Scientific Research, vol. 5, p. 153-161, 2012.

[29] M. V. Mallikarjun, V. R. Mamilla, and G. L. N. Rao, "NO ${ }_{x}$ emission control techniques when $\mathrm{CI}$ engine is fuelled with blends of mahua methyle esters and diesel," International Journal of Engineering Sciences \& Emerging Technologies, vol. 4, no. 2, pp. 96-104, 2013.

[30] O. M. Ali, R. Mamat, and C. K. M. Faizal, "Effects of diethyl ether additives on Palm biodiesel fuel characteristics and low temperature flow properties," International Journal of Science and Technology, vol. 52, pp. 111-120, 2013

[31] C. Cinar, O. Can, F. Sahin and H. S. Yucesu, "Effects of premixed diethyl ether on combustion and exhaust emissions in a HCCI-DI diesel engine," Applied Thermal Engineering, vol. 30, no. 4, pp. 360-365, 2010.

[32] D. C. Rakopoulos, C. D. Rakopoulos, E. G. Giakoumis, R. G. Papagiannakis, and D. C. Kyritsis, "Influence of properties of various common bio-fuels on the combustion and emission characteristics of high-speed DI (direct injection) diesel engine: Vegetable oil, bio-diesel, ethanol, n-butanol, diethyl ether," Energy, vol. 73, pp. 354-366, 2014.

[33] S. Hariharan, S. Murugan, and G. Nagarajan, "Effect of diethyl ethe on tyre pyrolysis oil fuelled diesel engine," Fuel, vol. 104, pp. 109-115, 2013.

[34] S. Sudhakar and S. Sivaprakasam, "Effect of diethyl ether fumigation in di diesel engine using bio ethanol blended diesel," International Journal of Innovation and Scientific Research, vol. 11, pp. 65-71, 2014.

[35] K. Purushothaman and G. Nagarajan, "Experimental investigation on a C.I. engine using orange oil and orange oil with DEE," Fuel, vol. 88, no. 9 , pp. $1732-1740$.

[36] Wikipedia. The free encyclopedia (diethyl ether). [Online]. Available: https://en.wikipedia.org/wiki/Diethyl-ether

[37] J. Devaraj, Y. Robinson, and P. Ganapathi, "Experimental investigation of performance, emission and combustion characteristics of waste plastic pyrolysis oil blended with diethyl ether used as fuel for diesel engine," Energy, vol. 85, pp. 304-309, 2015.

[38] Y. Zhao, Y. Wang, D. Li, X. Lei, and S. Liu, "Combustion and emission characteristics of a DME (dimethyl ether)-diesel dual fuel premixed charge compression ignition engine with EGR (exhaust gas recirculation)," Energy, vol. 72, pp. 608-617, 2014

[39] J. Hou, Z. Wen, Z. Jiang, and X. Qiao, "Study on combustion and emissions of a turbocharged compression ignition engine fuelled with dimethyl ether and biodiesel blends," Journal of the Energy Institute, vol. 87, no. 2, pp. 102-113, 2014.

[40] Y. Liang, G. Shu, H. Wei, and W. Zhang, "Effect of oxygen enriched combustion and water-diesel emulsion on the performance and emissions of turbocharged diesel engine," Energy Conversion and Management, vol. 73, pp. 69-77, 2013.

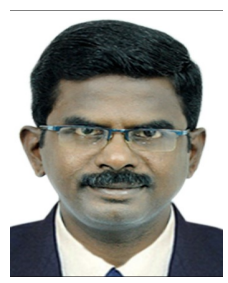

S. Murugan was born in 1968 in Tamil nadu, India $\mathrm{He}$ is an Associate Professor in the Mechanical Engineering Department at the National Institute of Technology, Rourkela, India. His area of interest includes alternative fuels for IC engines, energy sources, waste management and renewable energy.

Kapura Tudu is a research scholar in the Department of Mechanical Engineering, at the National Institute of Technology, Rourkela. Her area of research includes waste recycling, alternative fuels for internal combustion engines and pollution control.

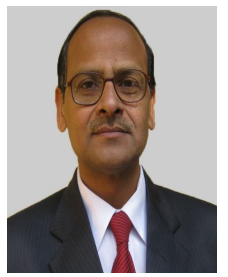

Saroj Kumar Patel is an Associate Professor in the Mechanical Engineering Department of the National Institute of Technology, Rourkela. He graduated in Mechanical Engineering from the National Institute of Technology, Rourkela in the year 1985. Initially, he served with Hindustan Aeronautics Limited, Koraput Division, India. He obtained his MTech degree from the Indian Institute of Technology Madras, Chennai and $\mathrm{PhD}$ degree from the Indian Institute of Technology Kharagpur, India. 